\author{
A. A. Safonov, O. I. Panasenko, Ye. G. Knysh
}

\title{
Synthesis, physical and chemical properties of 2-((4-(R-amino)- 5-(thiophen-2-ylmethyl)-4H-1,2,4-triazol-3-yl)thio)acetic acids salts
}

\author{
Zaporizhzhia State Medical University, Ukraine
}

Thanks to the rapid development of science, humanity has achieved remarkable success in various fields. This also applies to the synthesis of biological compounds. Over the centuries, scientists have invented many methods and drugs that are being actively used to date. Derivatives of 1,2,4-triazole can be the foundation for the manufacture of new native drugs that will compete with foreign ones.

The aim of work was synthesis and confirmation the structure of 2-((4-(R-amino)-5-(thiophen-2-ylmethyl)-4H-1,2,4-triazol-3-yl)thio) acetate acids salts.

Materials and methods. As starting substances we used 2-((4-(R-amino)-5-(thiophen-2-ylmethyl)-4H-1,2,4-triazol-3-yl)thio)acetic acids, which were synthesized by previously described methods. The structure of synthesized compounds was confirmed by the complex use of modern physical-chemical methods of analysis: elemental analysis, ${ }^{1} \mathrm{H}-\mathrm{NMR}$ spectroscopy, HPLC-MS.

Results. Salts of 2-((4-(R-amino)-5-(thiophen-2-ylmethyl)-4H-1,2,4-triazol-3-yl)thio)acetic acids were synthesized by the interaction of the appropriate acids with organic (morpholin, methanamin, 2-hydroxyethanamin), inorganic basics (aqueous ammonia solution, sodium hydroxide) and salts (zinc sulfate, ferrum (III) chloride, magnesium sulfate, copper (II) sulfate) in alcoholic or aqueous media. Conclusions. A series of novel 2-((4-(R-amino)-5-(thiophen-2-ylmethyl)-4H-1,2,4-triazol-3-yl)thio)acetic acids salts were synthesized. The structure of synthesized compounds is established using modern physical-chemical methods of analysis.

Key words: synthesis, 1,2,4-triazole, salts, chromato-mass spectrum.

Current issues in pharmacy and medicine: science and practice 2017; 10 (3), 259-263

Синтез, фізико-хімічні властивості солей 2-((4-(R-аміно)-5-(тіофен-2-ілметил)-4H-1,2,4-тріазол-3-іл)тіо)ацетатних кислот А. А. Сафонов, О. І. Панасенко, С. Г. Книи

Історія створення нових біологічно активних субстанцій бере початок ще з часів Стародавнього Єгипту. 3 кожним роком учені вдосконалювали методики синтезу БАР, створювали нові субстанції та провадили пошук перспективних сполук для створення ліків. У 21 столітті на планеті в день синтезується понад мільйон нових сполук, але тільки деякі з них можуть у перспективі стати ліками. Розглядаючи синтетичні можливості вітчизняної науки, варто відзначити похідні 1,2,4-тріазолу як потенційні субстанції з різними видами біологічної активності, на основі яких можуть бути створені оригінальні лікарські засоби.

Мета роботи - синтез і підтвердження будови солей 2-((4-(R-аміно)-5-(тіофен-2-ілметил)-4H-1,2,4-тріазол-3-іл)тіо)ацетатних кислот.

Матеріали та методи. Як вихідні речовини нами використані 2-((4-(R-аміно)-5-(тіофен-2-ілметил)-4H-1,2,4-тріазол-3-іл)тіо) ацетатні кислоти, що синтезовані за раніше описаною методикою. Будову синтезованих сполук підтверджено комплексним використанням сучасних фізико-хімічних методів аналізу: елементного аналізу, ${ }^{1} \mathrm{H}$-ЯМР-спектроскопії, ВЕРХ-MC.

Результати. Солі 2-((4-(R-аміно)-5-(тіофен-2-ілметил)-4H-1,2,4-тріазол-3-іл)тіо)ацетатної кислоти отримані взаємодією відповідних кислот з органічними (морфолін, метиламін, моноетаноламін), неорганічними основами (водний розчин амоніаку, натрій гідроксид) і солями (цинк сульфат, ферум (III) хлорид, магній сульфат, купрум сульфат) у спиртовому або водному середовищах.

Висновки. Синтезовано ряд нових солей 2-((4-(R-аміно)-5-(тіофен-2-ілметил)-4H-1,2,4-тріазол-3-іл)тіо)ацетатних кислот, будова яких встановлена за допомогою сучасних фізико-хімічних методів аналізу.

Ключові слова: синтез, 1,2,4-тріазол, солі, хромато-мас-спектри.

Актуальні питання фармацевтичної і медичної науки та практики. - 2017. - Т. 10, № 3(25). - С. $259-263$

Синтез, физико-химические свойства солей 2-((4-(R-амино)-5-(тиофен-2-илметил)-4H-1,2,4-триазол-3-ил)тио) ацетатных кислот

\section{А. А. Сафонов, А. И. Панасенко, Е. Г. Кныш}

История создания новых биологически активных субстанций берет начало еще со времен Древнего Египта. С каждым годом ученые совершенствовали методики синтеза БАВ, находили новые субстанции и вели поиск перспективных соединений для создания лекарств. В 21 веке на планете в день синтезируется более миллиона новых соединений и только некоторые из них могут в перспективе стать лекарством. Рассматривая синтетические возможности отечественной науки, следует отметить производные 1,2,4-триазола как потенциальные субстанции с различными видами биологической активности, на основе которых могут быть созданы оригинальные лекарственные средства.

Цель работы - синтез и подтверждение структуры солей 2-((4-(R-амино)-5-(тиофен-2-илметил)-4H-1,2,4-триазол-3-ил)тио) ацетатных кислот.

Материалы и методы. В качестве исходных веществ нами были использованы 2-((4-(R-амино)-5-(тиофен-2-илметил)-4H1,2,4-триазол-3-ил)тио)ацетатные кислоты, синтезированные по ранее описанной методике. Строение синтезированных соединений подтверждено комплексным использованием современных физико-химических методов анализа: элементного анализа, ${ }^{1} \mathrm{H}$-ЯМР-спектроскопии, ВЭЖХ-МС. 
Результаты. Соли 2-((4-(R-амино)-5-(тиофен-2-илметил)-4H-1,2,4-триазол-3-ил)тио)ацетатной кислоты получены взаимодействием соответствующих кислот с органическими (морфолин, метиламин, моноэтаноламин), неорганическими основаниями (водный раствор аммиака, натрий гидроксид) и солями (цинк сульфат, железа (III) хлорид, магний сульфат, меди сульфат) в спиртовой или водной средах.

Выводы. Синтезирован ряд новых солей 2-((4-(R-амино)-5-(тиофен-2-илметил)-4H-1,2,4-триазол-3-ил)тио)ацетатных кислот, строение которых установлено с помощью современных физико-химических методов анализа.

Ключевые слова: синтез, 1,2,4-триазол, соли, хромато-масс-спектры.

Актуальные вопросы фармацевтической и медицинской науки и практики. - 2017. - Т. 10, № 3(25). - С. 259-263

$\mathrm{T}$ he history of new biologically active substances' creation starts from the times of Ancient Egypt. Every year, scientists improved their synthesis techniques, created new substances and searched for promising compounds that could eventually become drugs.

More than million new compounds a day are synthesized on the planet in the 21 st century, but only some of them may become drugs. Considering synthetic possibilities of the national science, it should be noted, that derivatives of 1,2,4-triazol are potential substances with various types of biological activity [1-6], on the basis of which original medicines can be created. The salts of 2-((4-(R-amino)-5(thiophen-2-ylmethyl)-4H-1,2,4-triazol-3-yl)thio)acetic acids are promising class which is still poorly studied.

\section{The aim of work}

The aim of work was synthesis and confirmation the structure of 2-((4-(R-amino)-5-(thiophen-2-ylmethyl)-4H-1,2,4triazol-3-yl)thio)acetic acids salts.

\section{Materials and methods}

As starting substances we used 2-((4-amino-5-(thiophen-2-ylmethyl)-4H-1,2,4-triazol-3-yl)thio)acetic acid, 2-((4-((2-chloro-6-fluorobenzylidene)amino)-5-(thiophen2-ylmethyl)-4H-1,2,4-triazol-3-yl)thio)acetic acid and 2-((4-((2-hydroxybenzylidene)amino)-5-(thiophen-2-ylmethyl)-4H-1,2,4-triazol-3-yl)thio)acetic acid, which were synthesized by previously described methods [7].

The structure of synthesized compounds was confirmed by the complex use of modern physical-chemical methods of analysis: elemental analysis, $1 \mathrm{H}-\mathrm{NMR}$ spectroscopy, HPLC-MS.

The study of the physical and chemical properties of the compounds was carried out according to the methods presented in the State Pharmacopoeia of Ukraine. The melting point was determined on an automatic device OptiMelt Stanford Research Systems MPA100 (US production). The elemental composition of the compounds was installed on the elemental analyzer Elementar Vario L cube (CHNS) (standard is sulfanilamide). Chromato-mass spectral studies were performed on a liquid chromatograph Agilent 1260 Infinity HPLC equipped with a mass spectrometer Agilent 6120 (ionization in electric spray (ESI)), ${ }^{1} \mathrm{H}$ NMR spectra were recorded on a spectrometer "Mercury 400", solvent DMSO-D, internal standard - tetramethylsilane and deciphered using a computer program ADVASP 143

\section{Results and discussion}

Salts of 2-((4-(R-amino)-5-(thiophen-2-ylmethyl)-4H-1,2,4triazol-3-yl)thio)acetic acids were synthesized by the interaction of the appropriate acids with organic (morpholin (Ig,Il), methanamin (Ih), 2-hydroxyethanamin (Ij)), inorganic basics (aqueous ammonia solution (If), sodium hydroxide (Ia, Ik, Im)) and salts (zinc sulfate (Ie), ferrum (III) chloride (Ic), magnesium sulfate (Id), copper (II) sulfate (Ib)) in alcoholic or aqueous media.

The obtained compounds were recrystallized by propan2-ol for the analysis. The physical-chemical constants of the obtained compounds are shown in Table 1.

Sodium 2-((4-(R-amino)-5-(thiophen-2-ylmethyl)-4H1,2,4-triazol-3-yl)thio)acetate (Ia, Ik, Im)

$\mathrm{NaOH}(0.01 \mathrm{~mol})$ is diluted in $30 \mathrm{ml}$ of water and added to the 2-((4-(R-amino)-5-(thiophen-2-ylmethyl)-4H-1,2,4triazol-3-yl)thio)acetic acid $(0.01 \mathrm{~mol})$. This solution is heated on water bath to complete dissolution of the precipitate, evaporated and recrystallized by propan-2-ol. Substances Ia, Ik, Im are obtained.

Ammonium 2-((4-amino-5-(thiophen-2-ylmethyl)-4H1,2,4-triazol-3-yl)thio)acetate (If)

Solution of $\mathrm{NH}_{4} \mathrm{OH}$ is added to the 2-((4-amino-5-(thiophen-2-ylmethyl)-4H-1,2,4-triazol-3-yl)thio)acetic acid $(0.01 \mathrm{~mol})$. This solution is heated on water bath to complete dissolution of the precipitate, evaporated and recrystallized by propan-2-ol. Substance (If) is obtained.

Copper (II) 2-((4-amino-5-(thiophen-2-ylmethyl)-4H1,2,4-triazol-3-yl)thio)acetate (Ib)

$\mathrm{NaOH}(0.01 \mathrm{~mol})$ is diluted in $30 \mathrm{ml}$ of water and added to the 2-((4-amino-5-(thiophen-2-ylmethyl)-4H-1,2,4-triazol3 -yl)thio)acetic acid $(0.01 \mathrm{~mol})$. This solution is heated on water bath to complete dissolution. $0.005 \mathrm{~mol}$ of $\mathrm{CuSO}_{4}$ is added. Precipitate is filtered and washed with water, dried. Substance $(\mathrm{Ib})$ is obtained.

Zink 2-((4-amino-5-(thiophen-2-ylmethyl)-4H-1,2,4triazol-3-yl)thio)acetate (Ie)

$\mathrm{NaOH}(0.01 \mathrm{~mol})$ is diluted in $30 \mathrm{ml}$ of water and added to the 2-((4-amino-5-(thiophen-2-ylmethyl)-4H-1,2,4-triazol3 -yl)thio)acetic acid $(0.01 \mathrm{~mol})$. This solution is heated on water bath to complete dissolution. $0.005 \mathrm{~mol}$ of $\mathrm{ZnSO}_{4}$ is added. Precipitate is filtered and washed with water, dried. Substance (Ie) is obtained.

Magnesium 2-((4-amino-5-(thiophen-2-ylmethyl)-4H1,2,4-triazol-3-yl)thio)acetate (Id)

$\mathrm{NaOH}(0.01 \mathrm{~mol})$ is diluted in $30 \mathrm{ml}$ of water and added to the 2-((4-amino-5-(thiophen-2-ylmethyl)-4H-1,2,4-triazol3 -yl)thio)acetic acid $(0.01 \mathrm{~mol})$. This solution is heated on 
Table 1. Physical-chemical constants of 2-((4-(R-amino)-5-(thiophen-2-ylmethyl)-4H-1,2,4-triazol-3-yl)thio)acetic acids salts<smiles>[R]=Nn1c(Cc2cccs2)nnc1SCC(=O)O</smiles>

\begin{tabular}{|c|c|c|c|c|c|c|c|c|c|c|}
\hline \multirow{2}{*}{ № } & \multirow{2}{*}{$\mathrm{R}_{1}$} & \multirow{2}{*}{$\mathrm{R}$} & \multirow{2}{*}{ Molecular formula } & \multirow{2}{*}{$\begin{array}{l}\text { Melting } \\
\text { point }{ }^{\circ} \mathrm{C}\end{array}$} & \multirow{2}{*}{$\begin{array}{l}\text { Mol. } \\
\text { Wt. }\end{array}$} & \multirow{2}{*}{ Yeild } & \multicolumn{4}{|c|}{ Calculated/found } \\
\hline & & & & & & & C \% & $\mathrm{H} \%$ & $\mathrm{~N} \%$ & S \% \\
\hline la & $2 \mathrm{H}$ & $\mathrm{Na}$ & $\mathrm{C}_{9} \mathrm{H}_{9} \mathrm{~N}_{4} \mathrm{NaO}_{2} \mathrm{~S}_{2}$ & $>250$ & 292 & 78.47 & 36.98 & 3.10 & 19.17 & 21.94 \\
\hline $\mathrm{Ib}$ & $2 \mathrm{H}$ & $\mathrm{Cu}$ & $\mathrm{C}_{18} \mathrm{H}_{18} \mathrm{CuN}_{8} \mathrm{O}_{4} \mathrm{~S}_{4}$ & $>250$ & 602 & 86.38 & 35.90 & 3.01 & 18.61 & 21.30 \\
\hline Ic & $2 \mathrm{H}$ & $\mathrm{Fe}$ & $\mathrm{C}_{27} \mathrm{H}_{27} \mathrm{FeN}_{12} \mathrm{O}_{6} \mathrm{~S}_{6}$ & $238-240$ & 863 & 78.98 & 37.54 & 3.15 & 19.46 & 22.27 \\
\hline Id & $2 \mathrm{H}$ & $\mathrm{Mg}$ & $\mathrm{C}_{18} \mathrm{H}_{18} \mathrm{MgN}_{8} \mathrm{O}_{4} \mathrm{~S}_{4}$ & $>250$ & 563 & 69.34 & 38.40 & 3.22 & 19.90 & 22.78 \\
\hline le & $2 \mathrm{H}$ & $\mathrm{Zn}$ & $\mathrm{C}_{18} \mathrm{H}_{18} \mathrm{~N}_{8} \mathrm{O}_{4} \mathrm{~S}_{4} \mathrm{Zn}$ & $>250$ & 604 & 74.82 & 35.79 & 3.00 & 18.55 & 21.23 \\
\hline If & $2 \mathrm{H}$ & $\mathrm{NH}_{4}$ & $\mathrm{C}_{9} \mathrm{H}_{13} \mathrm{~N}_{5} \mathrm{O}_{2} \mathrm{~S}_{2}$ & $165-167$ & 287 & 74.35 & $\begin{array}{l}37.62 / \\
37.69\end{array}$ & $\begin{array}{l}4.56 / \\
4.54\end{array}$ & $\begin{array}{l}24.37 / \\
24.35\end{array}$ & $\begin{array}{l}22.32 / \\
22.36\end{array}$ \\
\hline $\lg$ & $2 \mathrm{H}$ & morpholinium & $\mathrm{C}_{13} \mathrm{H}_{19} \mathrm{~N}_{5} \mathrm{O}_{3} \mathrm{~S}_{2}$ & $223-225$ & 357 & 83.42 & $\begin{array}{l}43.68 / \\
43.59\end{array}$ & $\begin{array}{l}5.36 / \\
5.34\end{array}$ & $\begin{array}{l}19.59 / \\
19.63\end{array}$ & $\begin{array}{l}17.94 / \\
17.97\end{array}$ \\
\hline Ih & $2 \mathrm{H}$ & methanaminium & $\mathrm{C}_{10} \mathrm{H}_{15} \mathrm{~N}_{5} \mathrm{O}_{2} \mathrm{~S}_{2}$ & $184-186$ & 301 & 81.86 & $\begin{array}{l}39.85 / \\
39.80\end{array}$ & $\begin{array}{l}5.02 / \\
5.01\end{array}$ & $\begin{array}{l}23.24 / \\
23.28\end{array}$ & $\begin{array}{l}21.28 / \\
21.31\end{array}$ \\
\hline lj & $2 \mathrm{H}$ & 2-hydroxyethanaminium & $\mathrm{C}_{11} \mathrm{H}_{17} \mathrm{~N}_{5} \mathrm{O}_{3} \mathrm{~S}_{2}$ & $198-200$ & 331 & 74.35 & $\begin{array}{l}39.86 / \\
39.77\end{array}$ & $\begin{array}{l}5.17 / \\
5.19\end{array}$ & $\begin{array}{l}21.13 / \\
21.16\end{array}$ & $\begin{array}{l}19.35 / \\
19.37\end{array}$ \\
\hline Ik & $\begin{array}{l}\text { 2-chloro-6-fluoro- } \\
\text { benzylidene }\end{array}$ & $\mathrm{Na}$ & $\mathrm{C}_{16} \mathrm{H}_{11} \mathrm{CIFN}_{4} \mathrm{NaO}_{2} \mathrm{~S}_{2}$ & $171-173$ & 432 & 82.11 & 44.40 & 2.56 & 12.94 & 14.82 \\
\hline$\|$ & $\begin{array}{l}\text { 2-chloro-6-fluoro- } \\
\text { benzylidene }\end{array}$ & morpholinium & $\mathrm{C}_{20} \mathrm{H}_{21} \mathrm{CIFN}_{5} \mathrm{O}_{3} \mathrm{~S}_{2}$ & $148-150$ & 498 & 70.02 & $\begin{array}{l}48.24 / \\
48.11\end{array}$ & $\begin{array}{l}4.25 / \\
4.24\end{array}$ & $\begin{array}{l}14.06 / \\
14.04\end{array}$ & $\begin{array}{l}12.88 / \\
12.91\end{array}$ \\
\hline $\operatorname{Im}$ & 2-hydroxybenzylidene & $\mathrm{Na}$ & $\mathrm{C}_{16} \mathrm{H}_{13} \mathrm{~N}_{4} \mathrm{NaO}_{3} \mathrm{~S}_{2}$ & $157-159$ & 396 & 78.78 & 48.48 & 3.31 & 14.13 & 16.18 \\
\hline
\end{tabular}

water bath to complete dissolution. $0.005 \mathrm{~mol}$ of $\mathrm{MgSO}_{4}$ is added. Precipitate is filtered and washed with water, dried. Substance (Id) is obtained.

Ferrum (III) 2-((4-amino-5-(thiophen-2-ylmethyl)-4H1,2,4-triazol-3-yl)thio)acetate (Ic)

$\mathrm{NaOH}(0.01 \mathrm{~mol})$ is diluted in $30 \mathrm{ml}$ of water and added to the 2-((4-amino-5-(thiophen-2-ylmethyl)-4H-1,2,4-triazol3 -yl)thio)acetic acid (0.01 mol). This solution is heated on

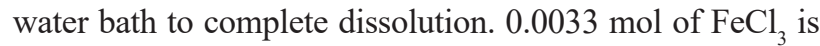
added. Precipitate is filtered and washed with water, dried. Substance (Ic) is obtained.

Morpholinium, methanaminium, 2-hydroxyethanaminium 2-((4-(R-amino)-5-(thiophen-2-ylmethyl)-4H-1,2,4triazol-3-yl)thio)acetate (Ig, Il, Ih, Ij)

Morpholin $(0.01 \mathrm{~mol})$ or methanamin $(0.01 \mathrm{~mol})$ or 2-hydroxyethanamin $(0.01 \mathrm{~mol})$ in accordance is diluted in $30 \mathrm{ml}$ of propan-2-ol and added to the 2-((4-(R-amino)-5-(thiophen-2-ylmethyl)-4H-1,2,4-triazol-3-yl)thio)acetatic acid ( $0.01 \mathrm{~mol})$ This solution is heated on water bath to complete dissolution, evaporated and recrystallized by propan-2-ol. Substances Ig, Il, Ih, Ij are obtained.

There is a peak of pseudomolecular ion $[\mathrm{MH}]^{+} \mathrm{m} / \mathrm{z} 410$ on the chromato-mass spectrum of the compound Ik (Gross formula $\mathrm{C}_{16} \mathrm{H}_{11} \mathrm{ClFN}_{4} \mathrm{NaO}_{2} \mathrm{~S}_{2}$, mol. wt. 432) (Fig. 1). It cor-

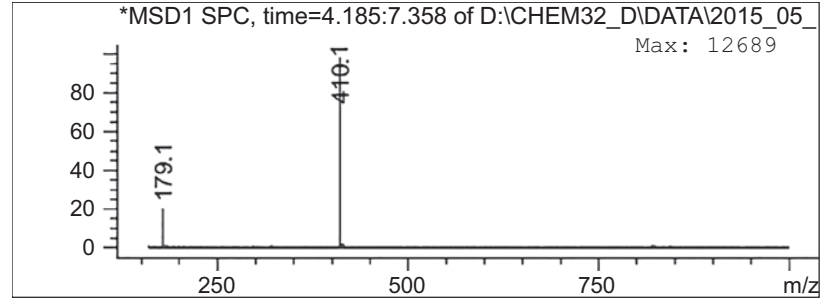

Fig. 1. A fragment of chromato-mass spectrum of sodium 2-(4-((2-chloro-6-fluorobenzylidene)amino)-5-(thiophen-2-ylmethyl)-4H-1,2,4-triazole-3-yl)thio)acetate (lk).

responds to the 2-(4-((2-chloro-6-fluorobenzylidene)amino)5-(thiophen-2-ylmethyl)-4H-1,2,4-triazole-3-yl)thio)acetate anion (mol. wt. 409).

There are signals of protons of two methylene groups, which are registered in the spectrum in the form of singlet at $3.52 \mathrm{ppm}(2 \mathrm{H})$ and $4.13 \mathrm{ppm}(2 \mathrm{H})$, protons of the amino group, which are fixed in the spectrum as the form of a singlet $(2 \mathrm{H})$ at $5.71 \mathrm{ppm}$, the protons of the thiophene cycle are fixed as the form of doublets at $6.68 \mathrm{ppm}(1 \mathrm{H}), 7.50 \mathrm{ppm}(1 \mathrm{H})$ and triplet $(6.96 \mathrm{ppm} .1 \mathrm{H})$. Proton of carboxyl group is absent on the ${ }^{1} \mathrm{H}$ NMR spectrum of sodium 2-((4-amino-5-(thiophen-2ylmethyl)-4H-1,2,4-triazol-3-yl)thio)acetate (Fig. 2). 


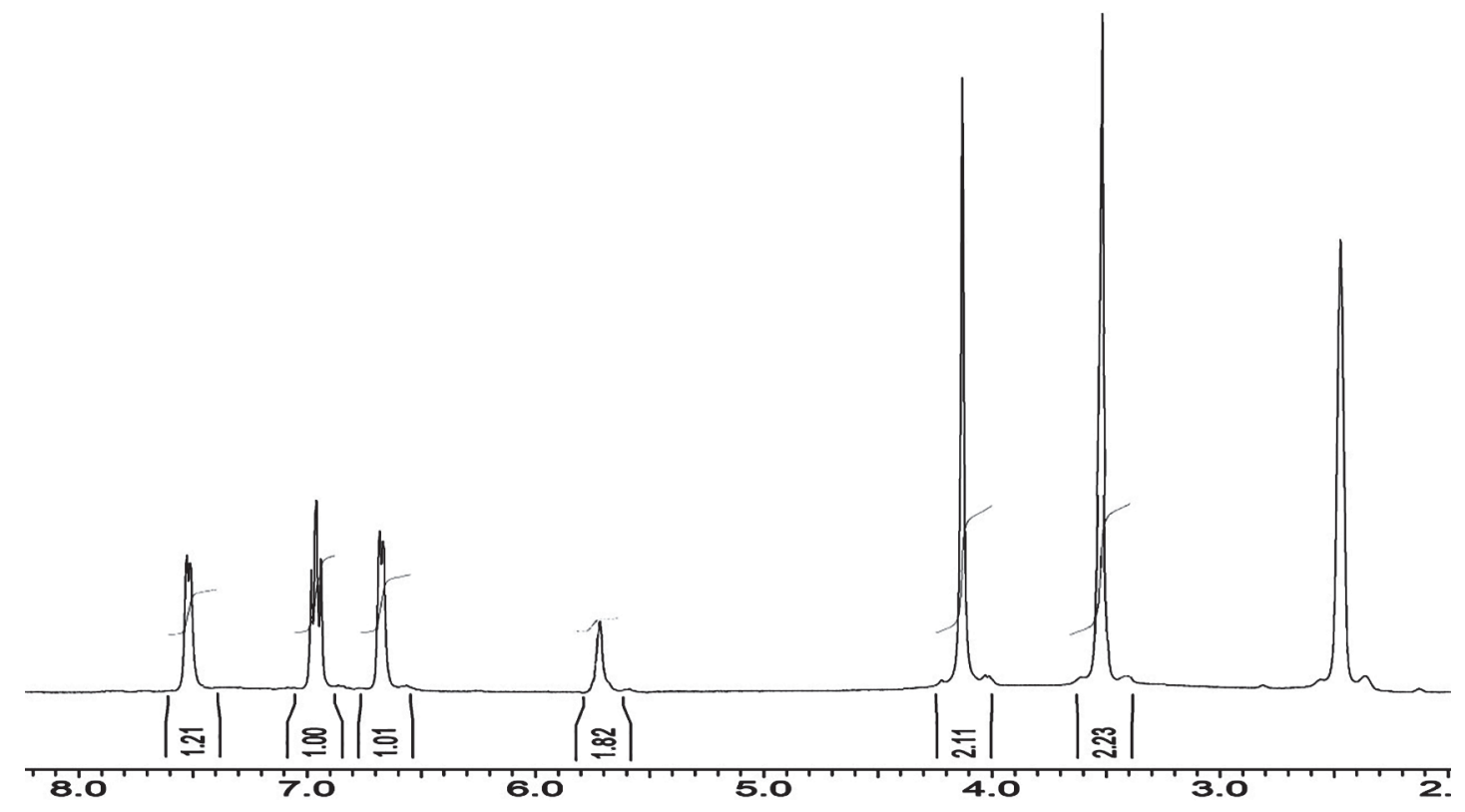

Fig. 2. ${ }^{1} \mathrm{H}-\mathrm{NMR}$ spectrum of sodium 2-((4-amino-5-(thiophen-2-ylmethyl)-4H-1,2,4-triazol-3-yl)thio)acetate (Compound la).

\section{Conclusions}

1. A series of novel 2-((4-(R-amino)-5-(thiophen-2-ylmethyl)-4H-1,2,4-triazol-3-yl)thio)acetic acids salts were synthesized.

2. The structure of synthesized compounds were established using modern physical-chemical methods of analysis.

Funding: The research was carried out within the state budget scientific-research work "Synthesis of new biologically active substances - derivatives of 5-(alkyl-, aryl-, heteryl-) of 4-R-(amino)-1,2,4-triazolyl-3-thiones for the creation of original drugs with analgesic, actoprotective, antimicrobial, anti-inflammatory and diuretic effect" (0115U003470), 2015-2017, funded by the Ministry of Health of Ukraine.

Фінансування: дослідження виконано в рамках держбюджетної науково-дослідної роботи «Синтез нових біологічно активних речовин - похідних 5-(алкіл-, арил-, гетерил-) похідних 4-R-(аміно)-1,2,4-тріазоліл-3-тіонів для створення оригінальних лікарських засобів 3 аналгетичною, актопротекторною, антимікробною, діуретичною та протизапальною дією», (0115U003470) 2015-2017, що фінансується МОЗ України.

\section{References}

[1] Brytanova, T. S., Pruhlo, Ye. S., Bilai, I. M., \& Knysh, Ye. H. (2012) Syntez ta hepatoprotektorna aktyvnist pokhidnykh 3,5-R-4-((5-nitrofuran-2-il)metylenamino- ta 3,5-R-4-(3(5-nitrofuran-2-il)alilidenamino)-1-R1-4N-1,2,4-triazolii halohenidiv [Synthesis and hepatoprotective activity of 3,5-R-4-((5-nitrofuran-2-il)methylenamino- та 3,5-R-4(3-(5- nitrofuran-2-il)allylidenamino)-1- $\mathrm{R}_{1}-4 \mathrm{H}-1,2,4-$ triazoliy halogenides derivateves]. Current issues in pharmacy and medicine: science and practice, 2, 176. [in Ukrainian].

[2] Patel, N. B., Khan, I. H., Pannecouque, C., \& De Clercq, E. (2013) Anti-HIV, antimycobacterial and antimicrobial studies of newly synthesized 1,2,4-triazole clubbed benzothiazoles. Med. Chem. Res., 22(3), 1320-1329.

[3] Bushueva, I. V., Parkhomenko, L. I., Knysh, Ye. G., \& Panasenko, O. I. (2014) Zastosuvannia morfolinii 2-5-(pirydyn-4-il)-1,2,4-triazol-3-iltio atsetatu dlia likuvannia i profilaktyky deiakykh zakhvoriuvan [Application of the morpholines of 2-[5-(pyridin-4-yl)-1,2,4-triazol-3-ylthio] acetates for the treatment and prevention of some diseases]. Zaporozhye medical journal, 2, 97-99. [in Ukrainian]. doi: https://doi. org/10.14739/2310-1210.2014.2.25443.
[4] Britanova, T. S., Pruglo, Ye. S., Hotsulya, A. S., Panasenko, A. I., \& Knysh, Ye. H. (2013) Vyvchennia diuretychnoi aktyvnosti ilidenpokhidnykh halohenidiv 3,5-R-4H-amino-r1,2,4-triazolu [Study of the diuretic activity ylidenderivatives halogenides of 3,5-R-4-amino-1,2,4-triazole]. Current issues in pharmacy and medicine: science and practice, 1(11), 18-20. [in Ukrainian].

[5] Pruhlo, Ye. S. (2016) Vplyv 4-benzylidenamino-5-fenil-4N-1, 2, 4-triazol-3-tioniv i solei 2-(4-amino-5-fenil-4N-1, 2, 4-triazol-3-iltio) atsetatnykh kyslot na tsentralnyi komponent notsytseptyvnoi systemy [Effect of 4-benzylidenamino-5-phenyl-4H-1,2,4-triazole-3-thiones and salts of 2-(4-amino-5-phenyl-4H-1,2,4-triazole-3-ylthio) acetic acid on central component of nociceptive system]. Current issues in pharmacy and medicine: science and practice, 2, 57-61. doi: 10.14739/2409-2932.2016.2.70699.

[6] Odyntsova, V. M. (2016) Protymikrobna ta protyhrybkova aktyvnist deiakykh zamishchenykh (5-(adamantan-1-il)-4R-1, 2, 4-triazol-3-iltioliv [Antimicrobial and antifungal activity of some (5-(adamantane-1-yl)-4R-1,2,4-triazole-3-ylthiols substitutes]. Current issues in pharmacy and medicine: science and practice, 3, 49-53. doi: 10.14739/24092932.2016.3.77945. 
[7] Safonov, A. A., Panasenko, O. I., Knysh, Ye. H., \& Samura, T. O. (2015) Syntez i fizyko-khimichni vlastyvosti 2-(4-(R-amino)5-(tiofen-2-ilmetyl)-4N-1,2,4-triazol-3-il)tioatsetatnykh kyslot
[Synthesis and physicochemical properties of 2-(4-(R-amino)5-(thiophen-2-ylmethyl)-4H-1,2,4-triazol-3-yl)thioacetate acids]. Odeskyi medychnyi zhurnal, 4, 13-16. [in Ukrainian].

\section{Information about the authors:}

Safonov A. A., Ph.D., Senior Lecturer, the Department of Toxicological and Inorganic Chemistry, Zaporizhzhia State Medical University, Ukraine.

Panasenko O. I., Dr.hab., Professor, Head of the Department of Toxicology and Inorganic Chemistry, Zaporizhzhia State Medical University, Ukraine.

Knysh Ye. G., Dr.hab., Professor, Head of the Department of Management and Pharmacy Economics, Medical and Pharmaceutical Commodity Research, Zaporizhzhia State Medical University, Ukraine.

\section{Відомості про авторів:}

Сафонов А. А., канд. фарм. наук, старший викладач каф. токсикологічної та неорганічної хімії, Запорізький державний медичний університет, Україна.

Панасенко О. І., д-р фарм. наук, професор, зав. каф. токсикологічної та неорганічної хімії, Запорізький державний медичний університет, Україна.

Книш Є. Г., д-р фарм. наук, професор, зав. каф. управління та економіки фармації, медичного і фармацевтичного правознавства, Запорізький державний медичний університет, Україна.

\section{Сведения об авторах:}

Сафонов А. А., канд. фарм. наук, старший преподаватель каф. токсикологической и неорганической химии, Запорожский государственный медицинский университет, Украина.

Панасенко А. И., д-р фарм. наук, профессор, зав. каф. токсикологической и неорганической химии, Запорожский государственный медицинский университет, Украина.

Кныш Е. Г., д-р фарм. наук, профессор, зав. каф. управления и экономики фармации, медицинского и фармацевтического правоведения, Запорожский государственный медицинский университет, Украина.

E-mail: 8Safonov@gmail.com

Конфлікт інтересів: відсутній.

Conflicts of Interest: authors have no conflict of interest to declare.

Надійшло до редакції / Received: 19.09.2017

Після доопрацювання / Revised: 22.09.2017

Прийнято до друку / Accepted: 02.10.2017 